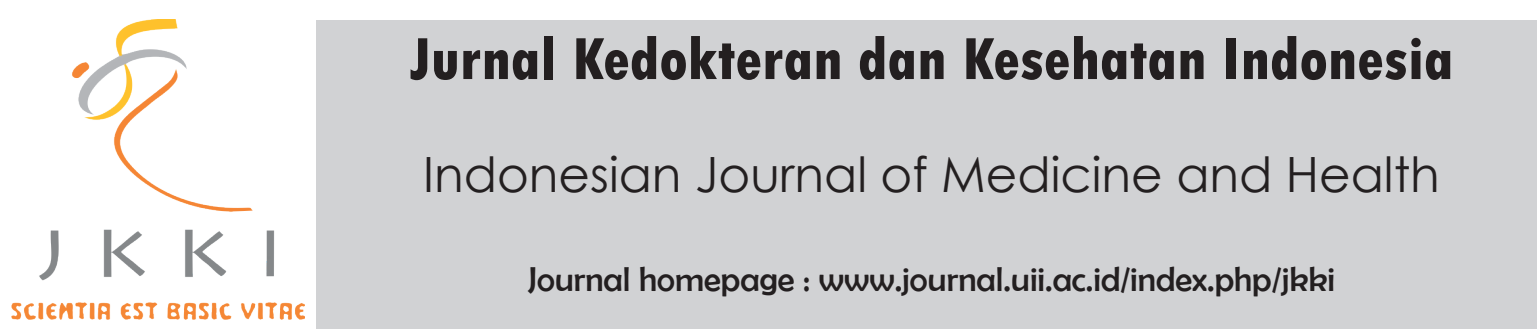

\title{
The effect of centella asiatica ethanolic extract on caspase-3 expression in prefrontal cortex of chronic restraint stress induced sprague dawley rat
}

Kuswati $^{1}$

${ }^{1}$ Department of Anatomy, Faculty of Medicine, Islamic University of Indonesia

Original Article

\section{ABSTRACT}

ARTICLE INFO

\section{Keyword:}

Chronic restraint stress,

Centella asiatica

Prefrontal cortex

*Corresponding author: kuswatinugroho@gmail.com

Introduction: Stress cause changes in the structure and function of the prefrontal cortex. Chronic restraint stress causes the shortening of dendrites in the medial prefrontal cortex. Centella asiatica is an herb that has antioxidant and neuroprotective effects. The purpose of this study is to understand the effect of Centella asiatica on the active protein caspase- 3 apoptosis executor expression in the prefrontal cortex.

Methods: This study was a laboratory experimental using posttest only control group design. The study used 25 pieces of stored biological material sample in the form of rat brain tissue paraffin blocks. These brain tissues came from 25 rats that were divided into groups of P1, P2, P3, P4 and P5. P1 group treated with restraint stress. Group P2, P3 and P4 were subjected to restraint stress and Centella asiatica ethanolic extract with therapeutic dose of 150 , 300 and $600 \mathrm{mg} / \mathrm{kg} /$ day. P5 group received stress treatment and fluoxetine with therapeutic dose of $10 \mathrm{mg} / \mathrm{kg}$ /day. On the $23 \mathrm{rd}$ day, termination, perfusion and brain tissues sampling were executed. Furthermore, the brain tissues were made into paraffin blocks, cut into specimen, immunohistochemical stained, and count the cells which were expressing active caspase-3

Results: There were significant differences in the expression of active caspase- 3 between P1 to P2, P3, P4 and P5 groups ( $=0.00$ ). There were no significant differences between P2, P3, P4 and P5 groups.

Conclusion: Centella asiatica ethanolic extract can inhibit active caspase-3 expression in the prefrontal cortex of Sprague Dawley rats that were induced with chronic restraint stress.

Pendahuluan : Stres mengakibatkan perubahan struktur dan fungsi pada cortex prefrontalis. Chronic restraint stress menyebabkan pemendekan dendrit pada cortex prefrontalis medial. Centella asiatica merupakan salah satu herbal yang memiliki efek antioksidan dan neuroprotektif. Tujuan penelitian ini adalah melihat efek centella asiatica terhadap ekspresi protein eksekutor apoptosis caspase-3 aktif di cortex prefrontalis.

Metode penelitian : Penelitian ini merupakan penelitian eksperimental laboratorik dengan menggunakan 
rancangan posttest only control group design. Penelitian ini menggunakan sampel dari bahan biologi tersimpan berupa blok parafin jaringan otak tikus sebanyak 25 buah. Jaringan otak tersebut berasal dari 25 ekor tikus terbagi dalam kelompok P1, P2, P3, P4 dan P5. Kelompok P1 mendapat perlakuan restraint stress Kelompok P2, P3 dan P4 mendapat perlakuan restraint stress dan terapi ekstrak etanol Centella asiatica 150, 300 dan 600 mg/kgbb/hari. Kelompok P5 mendapat perlakuan stres dan terapi fluoxetin $10 \mathrm{mg} / \mathrm{kgbb} / \mathrm{hari}$. Pada hari ke 23 dilakukan terminasi, perfusi dan pengambilan jaringan otak. Selanjutnya jaringan otak dibuat blok parafin, dibuat potongan preparat, pengecatan imunohistokimia dan penghitungan sel yang mengekspresikan caspase-3 aktif.

Hasil : Terdapat perbedaan bermakna ekspresi caspase-3 aktif antara kelompok P1 dengan P2, P3, P4 dan P5 $(p=0,00)$. Tidak terdapat perbedaan bermakna antara kelompok P2, P3, P4 dan P5.

Kesimpulan: Ekstrak etanol Centella asiatica dapat menghambat ekspresi caspase-3 aktif di cortex prefrontalis tikus Spraque Dawley yang diinduksi chronic restraint stress.

\section{INTRODUCTION}

Stress causes an increase of neurons stimulation in hypothalamus paraventricular nucleus to secrete corticotropin releasing factor hormone. The effect of these hormones will increase adrenocorticotropic hormones (ACTH) secretion from pituitary gland. Increase level of ACTH stimulates adrenal cortex to increase glucocorticoid hormones secretion. In the central nervous system, increase of glucocorticoids release will results in increase glutamate release. Glutamate binds to receptor N-MethylD-aspartate (NMDA). Glutamate and NMDA give excitatory effect on neurons, play a role in neuron neuroplasticity, learning and memory. Increase level of glucocorticoid, glutamate and NMDA receptors result in excitotoxic effects on neurons in the brain. ${ }^{1}$

The effect of stress on the cerebral cortex which was reviewed by Pittenger and Duman (2008) is chronic restraint stress that causing regression on branch apical dendrites of pyramidal cells in the medial prefrontal cortex and hippocampus CA3 area. Chronic unpredictable stress inhibits proliferation of glia cells and endothelial cells in the medial prefrontal cortex. Glia cells provide metabolic support to neurons. Decline number of glia cells results in neurons impaired function. Glia cells also play an important role in glutamate synthesis and inactivation which have effect on neuroplasticity. The decline number of glia cells may inhibit neuroplasticity. Stress cause increased volume (hypertrophy) of amygdala. Stress also cause increase on dendrites number and length in nuclues of stria terminalis amygdala. Prolonged stress increases dendritic spine and synaptic conectivity in amygdala. ${ }^{2}$

Medial prefrontal cortex plays an important part in the integration of cognitive and emotional as well as centralization of attention-related information that has been received. The medial prefrontal cortex also has higher levels of glucocorticoid receptors. Therefore, the prefrontal cortex is influenced by stress. Repeated stress results in a 16\% decrease of apical dendritic spine density in medial prefrontal cortex neurons. It is estimated that one third of axons and synapses total loss in apical dendrites pyramidal neurons in the medial prefrontal cortex caused by repeated stress. This situation may be caused by neuroplasticity failures as effects of exposure to stress. 3 In the prefrontal cortex, acute stress cause an increase of glutamate release and stimulate depolarization of neurons in the prefrontal cortex also cause atrophy in the anterior cingulate cortex (ACC) . ${ }^{1,4}$

Acute and chronic stresses lead to structural changes in the prefrontal cortex and amygdala. Restrain chronic stress and chronic immobilization cause dendrites shortening in the medial prefrontal cortex. At the amygdala neurons, restrain chronic stress and chronic immobilization lead to dendrite growth. In addition to structural changes, stress resulting in decreased function of the prefrontal cortex, such as impairment in attention, impairs extinction of a fear conditioning task. In the amygdala, chronic stress for 21 days resulted in experimental animal's hyperactivity and increased aggressiveness in cage. ${ }^{5}$

Centella asiatica is one of those herbs that have a neuroprotective effect which can be used to prevent neurons damage caused by stress and an increase in glucocorticoids. 
Madecassoside, asiaticoside, asiatic acid and madecassic acid contained in Centella asiatica extracts have antioxidant and neuroprotective effect. ${ }^{6}$ Centella asiatica extracts at doses of $150 \mathrm{mg} / \mathrm{KgBW}$ and $300 \mathrm{mg} / \mathrm{KgBW}$ given to rats that are experiencing stress proven to improve memory and inhibit oxidative stress in the brain by lowering malondialdehyde (MDA) and nitrite concentration as well as increasing antioxidant activity such as Gluthatione-strasferase, superoxide dismutase and katalase. ${ }^{7}$ Centella asiatica can increase dendrites length and dendrites number of branching on neurons in amigdala.8 Centella asiatica can increase neurons proliferation in the hippocampus CA3 and CA4 region. ${ }^{9}$

The purpose of this study is to determine Centella asiatica extracts effect on active caspase-3 expression in the prefrontal cortex of Sprague dawley rats treated with chronic stress.

\section{METHODS}

This research was a laboratory experimental using posttest only control group design. The research was conducted in Laboratory of Pathology Anatomy at RSUP DR.Sardjito Yogyakarta and Laboratory of Anatomy at Faculty of Medicine, Indonesia Islamic university on January-September 2015. This study was approved by the Ethics Committee of Medical Faculty of Medicine and Health Research, Indonesia Islamic University with the number 03/Chairman/70/KEFKUII/ III/2015.

The study used 25 pieces of biological material samples stored in the form of rat brain tissue paraffin blocks. The brain tissues came from 25 rats that were divided into P1, P2, P3, P4 and P5 groups. P1 group received stress treatment. P2 group received stress treatment and Centella asiatica ethanolic extracts therapy $150 \mathrm{mg} / \mathrm{kg} /$ day. P3 group received stress treatment and Centella asiatica ethanolic extracts therapy 300 $\mathrm{mg} / \mathrm{kg} /$ day. P4 group received stress treatment and Centella asiatica ethanolic extracts therapy $600 \mathrm{mg} / \mathrm{kg} /$ day. P5 group received stress treatment and fluoxetine $10 \mathrm{mg} / \mathrm{kg} /$ day therapy. Stress was done with restraint stress method in which rat was placed in a transparent acrylic tube with $15 \times 5.5 \mathrm{~cm}$ in size, 6 hours per day for 21 days. This situation made the rat could not move freely, causing psychological stress. The Centella asiatica ethanolic extract and fluoxetine were administered 30 minutes before the stress began. On the $23^{\text {rd }}$ day, termination, perfusion and brain tissues sampling were carried out. After that, brain tissues were made into paraffin blocks.

\section{Preparation of Centella asiatica extracts}

Centella asiatica was obtained from CV. Merapi Farma Herbal (commercial herbal manufacturer) in the form of simplicia. Centella asiatica was identified and determined in Laboratory of Plant Systematic at Faculty of Biology Gadjah Mada University with the number 0354/S.Tb/VI/2012.

Centella asiatica extracts was standardized with nonspecific standardization by checking the moisture content and specific standardization by identifying active compound using asiaticoside marker which was conducted with thin layer chromatography (TLC) method. The obtained Centella asiatica extracts contain asiaticoside amounted to $4.16 \pm 0.51 \%$.

Centella asiatica extracts were made into three concentrations of $30 \mathrm{mg} / \mathrm{ml}, 60 \mathrm{mg} /$ $\mathrm{ml}$, and $120 \mathrm{mg} / \mathrm{ml}$. The doses of Centella asiatica were $150 \mathrm{mg} / \mathrm{kgBW}, 300 \mathrm{mg} / \mathrm{kgBW}$, and $600 \mathrm{mg} / \mathrm{kgBW}$. Centella asiatica extract with concentration of $30 \mathrm{mg} / \mathrm{ml}$ was used for a dose of $150 \mathrm{mg} / \mathrm{kg}$, concentration of $60 \mathrm{mg} /$ $\mathrm{ml}$ for a dose of $300 \mathrm{mg} / \mathrm{kg}$ body weight, and the concentration of $120 \mathrm{mg} / \mathrm{ml}$ for a dose of $600 \mathrm{mg} / \mathrm{kg}$. Extracts dilution was conducted at the Laboratory of Pharmacology at Faculty of Medicine Gadjah Mada University every 3 days. Diluted extracts were stored in a refrigerator. The dose calculation formula of Centella asiatica extracts volume used for the rats is Volume $=$ dose $(\mathrm{mg} / \mathrm{kg}) \mathrm{X}$ body weight $(\mathrm{kg}) /$ concentration $(\mathrm{mg} / \mathrm{ml})$.

\section{Sectioning paraffin blocks}

Rat brain tissue paraffin blocks were sectioned into $4 \mu \mathrm{m}$ in thickness. Cuts were made on the part containing prelimbic, infralimbic and cortex cynguli area on Bregma $3.72 \mathrm{~mm}$ to $2.52 \mathrm{~mm}$ according to atlas of Paxinos \& Watson. ${ }^{10}$ One piece of sample was taken from each paraffin 
block rat brain tissue.

\section{Immunohistochemistry staining}

Immunohistochemistry staining made use of active caspase- 3 antibodies (santa cruz) and were carried out in Laboratory of Pathology Anatomy at RSUP DR. Sardjito Yogyakarta. The staining begins with deparaffinization using decreased concentration of xylol and alcohol. Then, the tissues were incubated with $\mathrm{H} 2 \mathrm{O} 2$ $3 \%$ in methanol $10 \%$ for 20 minutes. After that, wash the tissues using distilled water for $3 \mathrm{x}$ and followed by PBS for 3x. Next, Antigen retrieval was done with citrate buffer $\mathrm{pH} 6$ in the microwave. For approximately 10 minutes, the slices were heated in high temperature $\left(100^{\circ} \mathrm{C}\right)$, followed by med-low temperature for 20 minutes. Furthermore, cooled and wash again the slices using PBS for $3 \mathrm{x}$.

The slices were blocked with protein background snipper for 10 minutes. Without washing it again, the tissues were dropped with primary antibody (Ab) active caspase- 3 and incubated overnight in a temperature of $4^{\circ} \mathrm{C}$. When finished, wash with PBS for $3 x$ and incubate with Trekki Universal Link for 10 minutes. Then, Wash with PBS for $3 \mathrm{x}$ and continued incubation with horseradish peroxidase conjugated Streptavidin (SA-HRP complex) for 10 minutes. Wash again with PBS for $3 \mathrm{x}$.

The identification of labeled active caspase-3 pyramidal cells were performed with 3,3'-diaminobenzidine (1:100) for 5 minutes. The tissues were then washed with distilled water for $5 \mathrm{x}$ and continued with hematoxylin meyers counterstained for 1 minute. Wash with flowing water for 2 minutes. Dehydrate with ethanol $70 \%, 80 \%, 90 \%, 95 \%$ and $100 \%$ respectively for 1 minute and cleaned with xylene. Final step, the tissues were slip covered with canada balsam.

\section{Expressed active caspase- 3 cell counting}

Specimen's observations were carried out in the Laboratory of Anatomy at Faculty of Medicine, Indonesia Islamic University. The specimens were seen with Olympus CX 22 microscope connected to optilab camera. Counting the number of cells expressing active caspase- 3 was done on the medial prefrontal cortex that covers prelimbik, infralimbik and cyngulate cortex area. The specimens were seen with a light microscope at a magnification of 400 times. Cell count was performed on 10 of the visual field. The percentage of cells expressing active caspase- 3 is the number of cells expressing active caspase- 3 divided by the total number of cells multiplied by $100 \%$.

\section{Statistical Analysis}

Data acquired in the form of cells percentage, statistical analysis using one way Anova was performed to compare the mean number of cells between groups. Then proceed with the post-hoc test to determine which group has differences.

\section{RESULTS}

In the stress-induced group (P1), mean active caspase- 3 expression in prefrontal cortex neurons was $46.8 \%$. Caspase- 3 expression in this group was the highest compared with the group that received restraint stress treatment and Centella asiatica or fluoxetine therapy (group P2, P3, P4 and P5). The calculation results of active caspase- 3 expression can be seen in Table 1.

Statistical analysis with one-way ANOVA showed that there were significant differences in the calculation results of active caspase- 3 expression in the prefrontal cortex $(\mathrm{p}=0.000)$. Results of post hoc analysis showed a significant difference between the groups P1 to P2, P3, P4 and $\mathrm{P} 5$. There were no significant differences between P2, P3, P4 and P5 groups. The lowest caspase- 3 active expression was found in the group treated with stress treatment and fluoxetine therapy. 
Kuswati. The effect of centella asiatica ethanolic extract ...

Table 1 Mean active caspase-3 expression in prefrontal cortex

\begin{tabular}{lcccccc}
\hline & \multicolumn{5}{c}{ Treatment group } & \multirow{2}{*}{$\mathrm{P}$} \\
\cline { 2 - 5 } & $\mathrm{P} 1(\mathrm{n}=5)$ & $\mathrm{P} 2(\mathrm{n}=5)$ & $\mathrm{P} 3(\mathrm{n}=5)$ & $\mathrm{P} 4(\mathrm{n}=5)$ & $\mathrm{P} 4(\mathrm{n}=5)$ & \\
\hline $\begin{array}{l}\text { active } \\
\text { caspase-3 } \\
\text { expression }\end{array}$ & 46,8 & 4 & 4,8 & 2,6 & 2,8 & 0.000 \\
\hline
\end{tabular}

P1: stress-induced group; P2: stress+ Centella asiatica extracts 150 mg/kgBW/day; P3: stress+ Centella asiatica extracts $300 \mathrm{mg} / \mathrm{kgBW} /$ day; P4: stress+ Centella asiatica extracts $600 \mathrm{mg} / \mathrm{kgBW} /$ day; P5: stress+ fluoxetin $10 \mathrm{mg} / \mathrm{kgBW} /$ day.

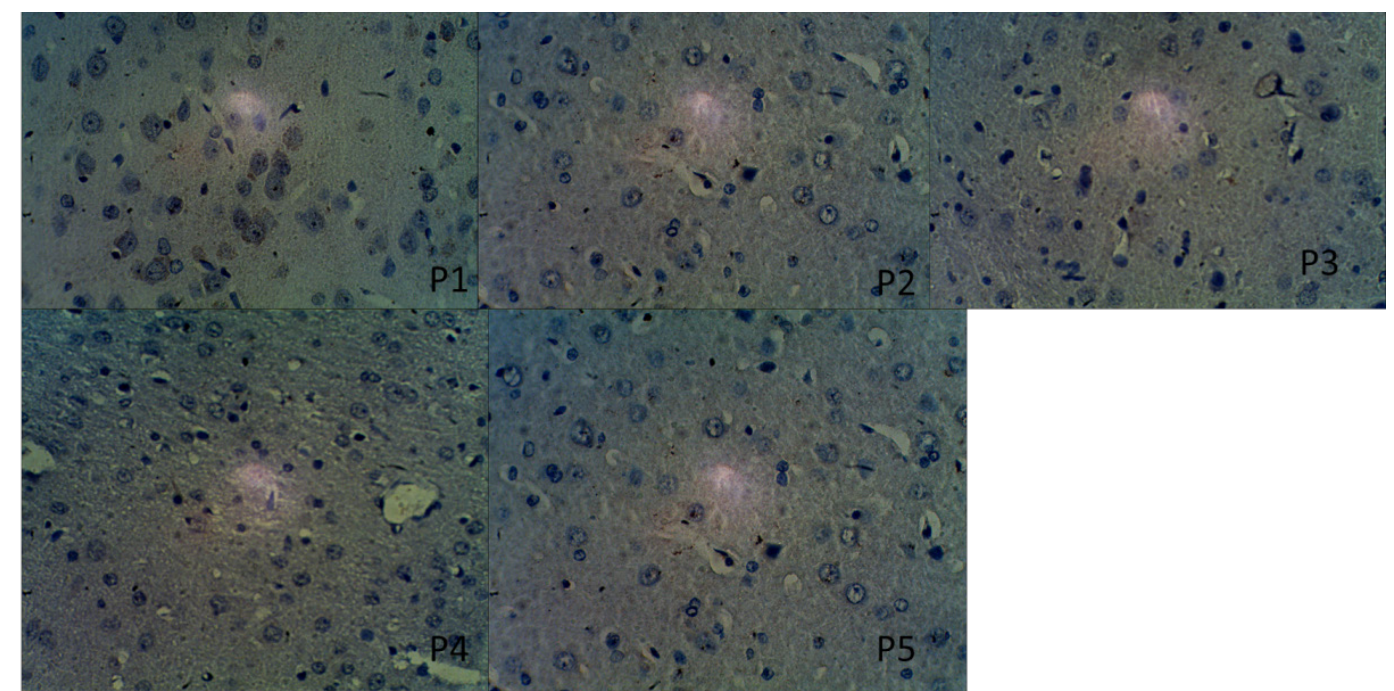

Figure 1 Active Caspase-3 expression in P1, P2, P3, P4 dan P5 groups

\section{DISCUSSION}

In this study the expression of active caspase-3 in Centella asiatica treatment groups (group P2, P3 and P4) were lower than the stress-induced group (P1). These showed that Centella asiatica ethanolic extracts with therapeutic dose of 150, 300 and $600 \mathrm{mg} / \mathrm{kg} /$ day for 21 days can reduce active caspase- 3 expression activity in the prefrontal cortex, thus decrease the number of cells undergoing apoptosis. Active caspase-3 is a protein executor in the apoptosis process through the intrinsic and extrinsic pathway. In the extrinsic pathway, active caspase- 3 and caspase-7 are proteolytic that can form DFF45 (DNA fragmentation factor-45). DFF45 cause chromosome degradation to be nucleosomes fragments which is apoptosis characteristic. ${ }^{11}$

The intrinsic apoptotic pathway involving Bcl-2 family proteins (Bcl-2 family) includes proapoptosis and antiapoptosis. Increased proapoptosis Bax protein expression and/ or a decreased antiapoptosis Bcl-2 protein can cause Bax and Bcl-2 balance disorders so that activated Bax forms homo-oligomers on the mitochondria outer membrane and lead to increased permeability of the mitochondrial membrane, resulting in cytochrome $\mathrm{C}$ released from mitochondria intermembrane space to the cytoplasm, Cytochrome C in the cytoplasm binds to Apaf-1 (apoptotic protease activating factor-1) forming apoptosom. Apoptosom activate procaspase- 9 into active caspase- 9 which is the apoptosis inisiator. Active caspase-9 activate caspase- 3 and caspase- 7 as apoptosis executor. $^{11,12}$

The results of this study support previous research conducted by Priyantiningrum (2015) that showed Centella asiatica ethanolic extracts with therapeutic dose of $300 \mathrm{mg} / \mathrm{kg} /$ day for 21 days in rats treated with chronic stress can 
increase the number of neurons in the prefrontal cortex. This increased number of neurons is due to Centella asiatica inhibit apoptosis..$^{13}$ It has been proven in other studies that Centella asiatica ethanolic extracts with a dose of 150, 300 and $600 \mathrm{mg} / \mathrm{kg} /$ day can increase pro-apoptotic $\mathrm{Bcl}-2$ protein expression in the medial prefrontal cortex of rats which have been induced with chronic restraint stress for 21 days. ${ }^{14}$

Asiaticoside contained in Centella asiatica have a neuroprotective effect and can inhibits cell death. Asiaticoside with a dose of 10 $\mu \mathrm{mol} / \mathrm{L}$ increase the cells viability in cultured cortical neurons. Asiaticoside can prevent cells damage from neurotoxicity induced by NMDA. NMDA cause decrease of Bcl-2, increase of Bax, and increase of $\mathrm{Bax} / \mathrm{Bcl}-2$ ratio. Asiaticoside treatment with a dose of $10 \mu \mathrm{mol} / \mathrm{L}$ can increase Bcl-2 expression, decrease Bax, and decrease Bax/Bcl-2 ratio. This matters showed that asiaticoside have antiapoptosis effects. ${ }^{15}$ NMDA exposure can increase NMDA receptors expression which is NR2B but not increase NR2A. NMDA receptor activation cause calcium to enter the cell, thereby increase intracellular calcium and cause neuronal damage. Administration of asiaticoside $10 \mu \mathrm{mol} / \mathrm{L}$ can inhibit NR2B increase level. The low expressions of NR2B cause a short opening of calcium channels so that a little calcium enters into the cells. Asiaticoside treatment with a dose of $10 \mu \mathrm{mol} / \mathrm{L}$ also can inhibit intracellular calcium increase level. The ability to inhibit NR2B expression and decrease intra-cell calcium underlying asiaticoside neuroprotective effect. ${ }^{15}$

In this study, the result of active caspase- 3 expression in Centella asiatica treatment group was not significantly different compared to fluoxetine treatment group. This suggests that the effect of antiapoptosis showed in Centella asiatica ethanolic extract equivalent to fluoxetine.

Fluoxetine is an antidepressant drug belongs to selective serotonin reuptake inhibitor (SSRI) group that increase serotonin levels in extracellular, inhibit serotonin transport into nerve terminal presinaps, and increase serotonin receptor affinity. Fluoxetine often used for depression treatment, compulsive behavior, and appetite disorders. ${ }^{16}$
In the central nervous system, fluoxetine proved to have some effects such as increase neurogenesis and increase dendrites branching in rat hippocampus, also increase polysialylated form of the neural cell adhesion molecule (PSA-NCAM) expression in cynguli cortex, hippocampus, and amygdala. ${ }^{17,18}$

In this study, the group that received fluoxetine therapy at a dose of $10 \mathrm{mg} / \mathrm{kg} /$ day (the P5) for 21 days can reduce active caspase- 3 expression in the prefrontal cortex. These results are consistent with Shishkina et al. (2012) which showed that fluoxetine administration for 8 weeks in rats treated with forced swim stress can increase mRNA Bcl-xl antiapoptosis gene expression and increase Bcl-xl/Bax ratio in brainstem. ${ }^{19}$ The other neuroprotective effects of fluoxetine were proven by Djorjevic et al. (2012) in his research that rats treated with chronic social isolation stress increase the expression of synaptosomal polysialic neural cell adnesion molecule (PSA-NCAM) in the prefrontal cortex. Treatment with fluoxetine can reduce PSA-NCAM levels. It showed that fluoxetine involved in neuroplasticity process in rat prefrontal cortex. ${ }^{20}$

Limitations of this study: This research only takes a specimen for every brain tissue paraffin block so that the number of samples was lacking a lot. Specimen observations only done on 10 field of view so it was not fully illustrating the overall cell number

\section{CONCLUSIONS}

From these results, it can be concluded that the Centella asiatica ethanolic extracts can decrease active caspase- 3 expression in the prefrontal cortex of Sprague Dawley rats induced with chronic restraint stress. Centella asiatica dose difference of $150 \mathrm{mg} / \mathrm{kg}, 300$ $\mathrm{mg} / \mathrm{kg}$ and $600 \mathrm{mg} / \mathrm{kg}$ did cannot decrease active caspase- 3 expression in the prefrontal cortex. Antiapoptosis effect of Centella asiatica ethanolic extracts through the inhibition of active caspase- 3 expression is equivalent to fluoxetine.

\section{SUGGESTION}

In order to get better research results, observations should be made in the entire field of view so that a wider observation area 
Kuswati. The effect of centella asiatica ethanolic extract ...

can be obtained. In addition, the number of sectioned specimen should be 3-5 pieces for 1 study subjects to obtain more samples. Further research is needed to understand other apoptosis parameter such as examination using TUNEL marker to count the number of cells undergoing apoptosis.

\section{ACKNOWLEDGEMENTS}

Author feel grateful for Research and Community Service Unit (UPPM), Faculty of Medicine, Indonesia Islamic University that provided research funding through internal grants in 2014.

\section{REFERENCES}

1. Heim,C., Nemeroff,C.B., Neorobiology of posttraumatic stress disorder. CNS Spectr, 200914 (1): 13-24.

2. Pittenger,C. and Duman,R.S., Stress, depression and neuroplasticity : a convergence of mechanisms. Neuropsychopharmacology,2008 33: 88-109.

3. Radley,J.J., Rocher,A.B., Miller,M., Janssen,W.G.M., Liston,C., Hof,P.R., McEwen, B.S., Morrison,J.H., Repeated stress induces dendritic spine loss in the rat medial prefrontal cortex, Cerebral cortex, 2006 16:313-320.

4. Musazzi,L., Milanese,M., Farisello,P., Zappettini,S., Tardito,D., Barbiero,V.S et al., Acute stress increases depolarizationevoked glutamate release in the rat prefrontal/frontal cortex : The dampening action of antidepressants, 2010 Available from : www.plosone.org 5: 1-11.

5. McEwen,B.S., Eiland.L., Hunter,R.G., Miller,M.M., Stress and anxiety : structural plasticity and epigenetic regulatin as aconsequence of stress, Neuropharmacology, 201262 : 3-12

6. Hashim,P., Sidek,H., Helan,M.H.M, Sabery,A., Palanisamy,U.D., Ilham,M., Triterpene Composition and Bioactivities of Centella asiatica, Molecules, 2011 16: 1310-22.

7. Kumar.A., Dogra,S. And Prakash,A. Neuroprotective effects of Centella asiatica against intracerebroventricular colchicineinduced cognitive impairment and oxidative stress, Int. J. Alzheimer. Dis,2009: 1-8

8. Rao, K.G.M., Rao,S.M., Rao,S.G., Enhancement of amygdaloid neuronal dendritic arborization by fresh leaf juice of Centella asiatica (Linn) during growth. eCAM, 20096(2) : 203-10.

9. Madhyasta.S, Somayaji,S.N, Bairy K.L., Prakash, Madhyasta,P., Neuroprotective effect of Centella asiatica leaf extract treatment on cognitition and hippocampal morphology against prenatal stress. Thai. J. Physiol. Sci, 2007 20: 79-88.

10. Paxinos,G. and Watson,C., The Rat Brain, 6th ed. Elsevier Inc. Philadelphia, 2007: 9-14

11. Tan,M.L, Ooi,J.P, Ismail,N., Moad,A.I.H, Muhammad,T.S.T, Programmed cell death pathways and current antitumor targets. Pharm. Res, 200926 (7) : 1547-56

12. Yan,N., Shi and Yigong, Mechanisms of apoptosis through structural biology. Annu. Rev. Cell. Dev. Biol, 2005 21: 35-51.

13. Priyantiningrum,A.K., Kuswati, Handayani,E.S, Pengaruh ekstrak etanol Centella asiatica terhadap jumlah sel neuron di cortex prefrontalis tikus yang diberi perlakuan stres. JKKI, 20156 (4): 198-207.

14. Kuswati, Prakosa.D., Wasita.B., Wiyono.W., Centella asiatica increase B-Cell Lymphoma 2 in rat Prefrontal Cortex. Univ med, 2015, 34 (1):10-16

15. Qi,F.Y., Yang,L., Tian,Z., Zha,M.G., Liu,S.B., An,J.Z., Neuroprotective effect of asiaticoside. Neural Regen Res, 20149 (13): 1275-82.

16. Berg,C., Backstrom,T., Winberg,S., Lindberg,R, Brandt,I., Developmental exposure to fluoxetine modulates the serotonin system in hypothalamus. Available from: www.plosone. org 2013 8: 1-7

17. Huang,G.J., David,E.B., Piella,A.T., Edward,A., Flint,J., et al., Neurogenomic evidence for a shared mechanism of the antidepressant effects of exercise and chronic fluoxetine in mice. Available from : www.plosone.org, 2012 7:1-9.

18. Guirado,R., Matarredona,D.S., Varea,E.,Crespo,C., Ibanez,J.M.B et al., Chronic fluoxetine treatment in middle aged rats induces changes in the expression of plasticity related molecules and in neurogenesis. BMC Neurosci, 201213 (5): 1-13.

19. Shiskina,G.T., kalinina,T.S., Berezova,I.V., Dygalo, N.N., Stress-induced activation of the brainstem $\mathrm{Bcl}-\mathrm{xl}$ gene ekspression in rats treated with 
JKKI 2015;7(2): 65-72

fluoksetine : Correlation with serotonin metabolism and depressive-like behavior. Neuropharmacology, 201262 : 177-83.

20. Djorjevic,A., Djorjevic,J., Elakovic,I, Adzic,M., matic,G., Radojcic,M.B, Effect of fluoksetine on plasticity and apoptosis evoked by chronic stress in rat prefrontal cortex. Eur. J. Pharmacol, 2012693 (1-3) : 37-44. 